\title{
Culture conditions for growth of clinical grade human tissue derived mesenchymal stem cells: comparative study between commercial serum-free media and human product supplemented media
}

\author{
Arati A. Inamdar ${ }^{1,2^{*}}$ and Ajinkya C. Inamdar ${ }^{2}$ \\ *Correspondence: inamdar@rci.rutgers.edu \\ ${ }^{1}$ Department of Plant Biology and Pathology, Rutgers, The State University of New Jersey, USA. \\ ${ }^{2}$ Saiseva Biotech Pvt. Ltd, India.
}

\begin{abstract}
Background: Large scale high quality and low cost production of clinical grade mesenchymal stem cells (MSCs) is critical for facilitating clinical research and potential stem cell therapies. Use of Fetal Bovine/Calf serum (FBS/FCS) for the clinical application carries a risk for transmission of zoonosis, therefore alternative xeno-free cell culture techniques have been evaluated. The commercial products for the culture of MSCs in xeno-free and/or serum free media such as STEMPRO ${ }^{\circ}$ MSC SFM and Mesen $\mathrm{Gro}^{\circ}$ are available but possibly not cost effective for large scale production of MSCs. The usage of human serum and pooled human platelet lysate (pHPL) present xeno-free alternatives as growth supplements.

Methods: In this report, we analyzed the growth potentials of human tissue derived MSCs from bone marrow (BM), umbilical cord tissue (UCT) and umbilical cord blood (UCB) in presence of xeno-free, serum free commercial culture media $\left(\mathrm{STEMPRO}^{\circ} \mathrm{MSC} \mathrm{SFM}\right.$ and MesenGro ${ }^{\circ}$ ) and serum containing media supplemented with pHPL, FBS and human serum. We also evaluated the role of surface of culture flasks for the optimal production of MSCs from these tissues by comparing the expansion potential of MSCs in culture flasks from Costar ${ }^{\circledast}$, CellBIND $^{\circledast}$, Greiner ${ }^{\circledast}$ and Tarsons ${ }^{\circledast}$ brands.

Results: We compared the growth potentials of these MSCs derived from these human tissues and found that pHPL supplemented culture media serves as an efficient, cost effective xeno-free media to produce clinical grade human MSCs for clinical applications. Interestingly, out of two commercial media, MesenGro ${ }^{\circledR}$ demonstrated better isolation and expansion potential than STEMPRO ${ }^{\circ}$ MSC SFM indicating that composition of commercial media affected the MSCs isolation and expansion although MSCs showed similar phenotypic characteristics and post cryopreservation viability. The MSCs production was at best in culture flasks with CellBIND ${ }^{\circ}$ surface treatment.

Conclusion: We conclude that pHPL supplemented media provide cost effective and efficacious way to produce clinical grade MSCs from various human tissues as opposed to commercial media. We showed that UCT can be an alternative option for large number of MSCs and unique surface treatment of cell culture flasks such as CellBIND ${ }^{\circ}$ facilitates large scale production of MSCs from various human tissues.
\end{abstract}

Keywords: Mesenchymal stem cells (MSCs), fetal bovine serum (FBS), pooled human platelet lysate (pHPL), human serum (HS), cryopreservation, viability

\section{Introduction}

Mesenchymal stem cells (MSCs)-based therapies are becoming backbone for the regenerative medicine. Multiple clinical studies confirm the safety of allogenic and autologous human MSCs for treatment of human diseases [1,2] MSCs are multipotent, non-hematopoietic stem cells with anti-inflammatory, immunomodulatory and regenerative properties, and are explored for their therapeutic potential in inflammatory, autoimmune and degenerative conditions in preclinical and clinical studies [3-5]. Autologous and allogenic MSCs can be isolated from bone marrow (BM), umbilical cord tissue (UCT), umbilical cord blood (UCB), adipose tissue (AT), periosteum, trabecular bone, synovium, skeletal muscle, deciduous teeth, fetal pancreas, lung, liver, amniotic fluid and placenta $[6,7]$.

The characteristics of MSCs are defined using three criteria: plastic-adherence; expression of specific surface markers (CD73, CD90, CD105) along with lack of expression of 'hematopoietic markers (CD14, CD34, CD45) and human leukocyte antigen,
HLA-DR; and capacity to self-renew and differentiate into various mesodermal lineages in vitro, including bone, cartilage, and adipose [8].

The promise of MSCs as a therapeutic agent for wide range of human conditions demands for the optimization of culture conditions to obtain large scale clinical grade MSCs with defined safety standards $[\mathbf{9 , 1 0 ]}$. Human serum, platelet rich plasma and human platelet lysate show similar or even enhanced growth potential for UCB, UCT, BM or AT derived MSCs than FBS $[11,12]$. Addition of serum to culture media provides the cells with vital nutrients, attachment factors, and growth factors. The presence of FBS/FCS in the growth media for MSCs is a source of xenogeneic antigens leading to a risk of infusion reactions and poses the risk of transmitting zoonotic diseases [13]. Human derived alternatives to animal origin supplements are human serum (autologous or allogenic), human plasma, cord blood serum, human platelet derivatives including platelet lysate, and platelet released factors [14-18]. 
Table 1. The table showing the different media and their composition used to compare the growth potential of MSCs derived from BM, UCB and UCT.

\begin{tabular}{ll}
\hline Media & Supplement \\
\hline Alpha MEM & $10 \%$ FBS \\
Alpha MEM & $10 \%$ pHPL \\
Alpha MEM & $10 \%$ Human Serum \\
STEMPRO $^{\circ}$ MSC SFM Xenofree & N/A \\
MesenGro $^{\circ}$ & N/A \\
\hline
\end{tabular}

Some studies comparing the effects of pHPL supplemented media and the FBS supplemented media on the growth of MSCs have been published; however, there are only few studies comparing the effect of commercially available serumfree and xeno-free media and the human serum or blood products containing media on the growth of MSCs [19-21]. The commercially available MSC growth media are expensive but chemically defined. Such media are also devoid of any donor related variability as they are supplemented with human recombinant or synthetic growth factors/cytokines shown to support the growth potency of human MSCs [20-21]. In this report, we compared the phenotype, growth potential and functional characteristics of MSCs derived from different human tissues (BM, UCT, UCB) on commercially available media, StemPro ${ }^{\circledR}$ MSC SFM XenoFree (Invitrogen) and MesenGro ${ }^{\circ}$ (StemRD) with media supplemented with human serum, pHPL or FBS.

Our data demonstrate the differential effects of these media on isolation and growth potential of MSCs derived from BM, UCB and UCT. Especially, MesenGro ${ }^{\circledR}$ supported the expansion potential of MSCs better than StemPro ${ }^{\circledR}$ MSC SFM XenoFree media. Growth of UCT derived MSCs was best supported by pHPL supplemented growth media. Overall, our data suggest that platelet derived growth factors are optimum way to provide convenient and economical production of large scale clinical grade MSCs for clinical application with inherent safety form xenogenic immunological reactions. In addition, the surface treatment of culture flasks plays an important role in facilitating large scale production of MSCs from human tissues.

\section{Materials and methods}

\section{Cell culture media and supplements}

Alpha MEM (a-MEM) with Glutamax without nucleosidases (Life Technologies, USA) was used as the basal cell culture medium. It was supplemented with various serum supplements as mentioned below:

a) $10 \%$ FBS (Life Technologies)

b) $10 \%$ human serum

c) $10 \% \mathrm{pHPL}$

The commercial products, STEMPRO ${ }^{\circledR}$ MSC SFM (Invitrogen) and MesenGro ${ }^{\oplus}$ (StemRD) (supplied as basal media and supplementary growth media) were prepared according to the manufacturer's directions. The culture flasks were coated with CELLstart ${ }^{\mathrm{TM}}$ xeno-free substrate prior to $\mathrm{STEMPRO}^{\circledR} \mathrm{MSC}$ SFM xeno-free and serum free medium for optimal growth of MSCs. The culture flasks $\left(25 \mathrm{~cm}^{2}\right.$ or $\left.75 \mathrm{~cm}^{2}\right)$ were purchased from Corning, USA (CellBIND ${ }^{\circledR}$ and $\left.\operatorname{Costar}^{\circledR}\right)$, Tarsons ${ }^{\text {TM }}$ Pvt. Ltd., India (Tarsons ${ }^{\mathrm{TM}}$ ) and Greiner Bio-One, USA (Greiner ${ }^{\circledR}$ ) in order to evaluate the importance of CellBIND ${ }^{\circledR}$ surface treatment for improved MSCs growth. Three samples of BM, UCT and UCB were assigned for each culture condition as mentioned in (Table 1). All experiments were performed in cGMP facility under Class 100 Biosafety cabinet in a Class 10,000 core clean room. The culture media and other reagents were kept at $37^{\circ} \mathrm{C}$ water bath before adding to the tissue or cell samples. The flasks were maintained in humidified atmosphere set at $37^{\circ} \mathrm{C}$ with 5\% $\mathrm{CO}_{2}$ (170 S Galaxy ${ }^{\oplus}$, Eppendorf/New Brunswick, USA).

\section{Preparation of Human serum}

Human serum was obtained using the published protocol with slight modification [12]. Three hundred and fifty milliliters of blood from each of the six healthy human donors with $A B$ blood group was collected in the collection bags and immediately aliquoted into $50 \mathrm{ml}$ centrifuge tubes. Each blood sample was screened for Hepatitis A, B and C, and HIV I and II. The centrifuge tubes were left undisturbed overnight at $4^{\circ} \mathrm{C}$. Then tubes were centrifuged at 2,000 $\mathrm{g}$ for 15 minutes and supernatants were pooled together, filter sterilized with $0.22 \mu \mathrm{m}$ syringe filters (Celltreat ${ }^{\oplus}, \mathrm{USA}$ ) and stored at minus $80^{\circ} \mathrm{C}$ until used.

Preparation of Pooled Human Platelet Lysate (pHPL) pHPL was prepared from pooled platelet rich plasma (PRP) with some modification of the protocol described previously [22]. Human peripheral blood $(n=10)$ was collected in 350 $\mathrm{ml}$ blood bags containing $49 \mathrm{ml}$ of CPDA from O positive blood group healthy donors. All samples were screened for Hepatitis A, B and C, and HIV I and II. Platelet counts were conducted for all samples. Blood bags were centrifuged in a refrigerated centrifuge (REMI KBM 70 plus, REMI ${ }^{\circledR}$ ) at $110 \mathrm{~g}$ at $4^{\circ} \mathrm{C}$. The plasma was collected in $50 \mathrm{ml}$ centrifuge tubes and again centrifuged at $2000 \mathrm{~g}$ to give two layers designated as upper and lower layers for platelet poor plasma (PPP) and platelet rich plasma (PRP), respectively. Platelet rich plasma were pooled together and allowed to undergo four freezethaw cycles to release platelet derived growth factors after platelet lysis. The lysed platelet debris was removed through centrifugation at $2000 \mathrm{~g}$ for $15 \mathrm{~min}$. The pooled HPL were filter sterilized with 0.22 um filter (Celltreat $^{\circledR}$, USA) and stored at minus $80^{\circ} \mathrm{C}$ until used.

\section{Collection and isolation of MSCs from BM, UCT and UCB}

Approval of protocols for collection of bone marrow, umbilical cord tissue and umbilical cord blood was obtained from the 
Inamdar et al. Journal of Regenerative Medicine \& Tissue Engineering 2013,

Ethics Committee.

Collection and Isolation of Bone Marrow Mesenchymal Stem Cells (BMMSC)

$5 \mathrm{ml}$ of bone marrow ( $\mathrm{n}=21)$ was extracted from the posterior iliac crest of healthy volunteers at the hospital with appropriate donor informed consents. Mononuclear cells (MNCs) were isolated from each BM sample using Ficoll Paque Premium (GE Life sciences, USA, density $=1.078 \mathrm{~g} / \mathrm{ml}$ ) density gradient method according to the supplier's protocol. Briefly, collected BM aspirates were diluted with equal volume of DPBS (Life Technologies) and layered onto Ficoll paque and then centrifuged at $400 \mathrm{~g}$ for $30 \mathrm{~min}$ at $20^{\circ} \mathrm{C}$. The mononuclear cell layer present at the interphase of upper layer of plasma and platelets and lower layer of Ficoll paque and RBCs was collected by a sterile pipette and washed twice in DPBS. The collected MNCs were further processed with Ficoll Paque Premium (GE Life sciences, USA, density $=1.073 \mathrm{~g} / \mathrm{ml}$ ) to enable the selective isolation of MSCs. The isolated MSCs enriched were then seeded into tissue culture treated T75 $\left(75 \mathrm{~cm}^{2}\right.$ ) flasks (Costar ${ }^{\circledR}$, CellBIND ${ }^{\circledR}$, Greiner $^{\circledR}$ and Tarsons ${ }^{\circledR}$ ) at a cell concentration of $1 \times 10^{4} \mathrm{cell} / \mathrm{s} / \mathrm{cm}^{2}$ using different cell culture media as summarized in (Table 1 ).

\section{Collection and Isolation of Umbilical cord blood (UCB MSC)}

Umbilical cord blood ( $n=21$ ) was collected from the healthy donors after $\mathrm{CS}$ deliveries after obtaining donor informed consents in CPDA containing collection bags. MNCs were isolated from CB samples using density gradient method as described above with Ficoll Paque Premium. MNCs were seeded into tissue culture treated T75 flasks (Costar ${ }^{\oplus}$, CellBIND ${ }^{\circledast}$, Greiner $^{\oplus}$ and Tarsons ${ }^{\oplus}$ ) at a cell concentration of $1 \times 10^{4} \mathrm{cell} / \mathrm{s} / \mathrm{cm}^{2}$ using different cell culture media as summarized in (Table 1 ).

Collection and Isolation of Umbilical Cord Tissue/ Wharton's Jelly Mesenchymal Stem Cells (UCTMSC) Umbilical cord tissues $(n=21)$ from cesarean section (CS) deliveries were collected after obtaining donor informed consents. Tissue was collected in the medium consisting of alpha MEM (a-MEM) with Glutamax, supplemented with $5 \mathrm{ug} / \mathrm{ml}$ Gentamicin, $2.5 \mathrm{ug} / \mathrm{ml}$ Amphotericin B (all from Life Technologies, USA) and 2 units $/ \mathrm{ml}$ heparin (Sigma Aldrich, USA). Tissue was washed in DPBS supplemented with $5 \mathrm{ug} / \mathrm{ml}$ Gentamicin and $2.5 \mathrm{ug} / \mathrm{ml}$ Amphotericin B and then blood vessels form the tissue were dissected. The tissue was cut into $0.5 \mathrm{~cm}^{2}$ pieces normalized for their length and weight before placing into T25 $\left(25 \mathrm{~cm}^{2}\right)$ flasks (Costar ${ }^{\circledast}$, CellBIND ${ }^{\circledR}$, Greiner $^{\circledast}$ and Tarsons $^{\circledast}{ }^{\oplus} 2 \mathrm{~cm}$ apart under different cell culture media as summarized in (Table 1 ).

\section{Propagation and Subculture of MSCs}

The cell culture media with appropriate serum supplements or STEMPRO ${ }^{\oplus}$ MSC SFM or MesenGro ${ }^{\circledR}$ (Table 1) were replaced
$72 \mathrm{hrs}$ from flasks implanted with MNCs from BM and UCB and after 7 days from UCT implanted flasks. Subsequently, same media were changed every alternate day until cells were $70-80 \%$ confluent. The fibroblastoid cells from BM, UCB and UCT were incubated with $1 X$ TrypLE $^{\mathrm{TM}}$ Select (Life Technologies), harvested and then counted using hemocytometer in duplicates. For subculture of MSCs, the cells with $70 \%$ confluence were separated using $1 X$ TrypLE $^{\mathrm{TM}}$ Select and then seeded at a density of $1 \times 10^{4} \mathrm{cells} / \mathrm{cm}^{2}$ in $75 \mathrm{~cm}^{2}$ flasks with the culture medium without the antibiotics and grown in humidified atmosphere at $37^{\circ} \mathrm{C}$ and $5 \% \mathrm{CO}_{2}$. The cells were studied till passage 7 .

\section{Evaluation of MSC Proliferation}

The proliferation of MSCs under different culture media was assessed using appropriate kinetic for calculation of population doubling (PD) rate and generation time as described by Biebek et al., (2008). The passaged cells were allowed to reach confluence of $80 \%$. The PD rate was determined using the following formula.

$X=\frac{\log 10\left(N_{H}\right)-\log 10\left(N_{1}\right)}{\log 10(2)}$

where $N_{H}$ is the harvested cell number and $N_{1}$ is the plated cell number. Cumulative population doublings (CPD) was calculated by adding the PD of each passage to the PD of previous passages.

The generation time (average time between two cells doublings) for the BM, UCT and UCB on different media was calculated for P2 and P6 using the following formula.

$$
X=\frac{\log 2 x \Delta t}{\log 10\left(N_{H}\right)-\log 10\left(N_{1}\right)}
$$

\section{Immunophenotyping with Flowcytometry}

Immunophenotypic analyses were performed on three batches of BM-MSC, UCT-MSC and UCB-MSC from all the groups (Table 1). Cells from P3 stage were used for performing Flowcytometry. The cells were dissociated with $1 \mathrm{X}$ TrypLE $^{\mathrm{TM}}$ Select and washed with DPBS before analysis. $1 \times 10^{6}$ cells were re-suspended in the $100 \mu \mathrm{l}$ buffer (10 mM HEPES, $140 \mathrm{mM}$ $\mathrm{NaCl}, 2.5 \mathrm{mM} \mathrm{CaCl}$, $\mathrm{pH}$ 7.4). Cells were incubated with the $5 \mu \mathrm{l}$ of following conjugated-antibodies: CD 45 (Anti-Human CD45 (LCA) FITC), CD 73 [Anti-Human CD73 PE (AD2)], CD 90 [Anti-Human CD90 (Thy1, Thy-1) PE], CD 34 (Fluorescein isothiocyanate (FITC) anti-human CD34), CD 105 (anti-human CD105 PE), and HLA-DR (anti-human HLA-DR FITC LN3) (all from eBioscience, USA) at room temperature in dark. Cells were analyzed with Guava ${ }^{\circledR}$ EasyCyte ${ }^{\mathrm{TM}}$ Flowcytometer for cell surface markers and the data was processed in CytoSoft 5.3 version (CA, USA).

Viability analysis

The viability of MSCs prior to cryopreservation and after 
Table 2. The table showing the protocol followed to cryopreserve the MSCs derived from BM, UCB and UCT (Adapted from Can and Balci, 2011).

\begin{tabular}{cccc}
\hline Step & Temperature $\left({ }^{\circ} \mathrm{C}\right)$ & Rate $\left({ }^{\circ} \mathrm{C} /\right.$ min $)$ & Time $(\mathbf{m i n})$ \\
\hline Start & 5 & 0 & 0 \\
1 & 0 & 2 & 2.5 \\
2 & 0 & 0 & 10 \\
3 & -6 & 1 & 6 \\
4 & -45 & 60 & 0.65 \\
5 & -26 & 10.96 & 1.73 \\
6 & -15 & 3 & 3.67 \\
7 & -35 & 1 & 22 \\
8 & -80 & 5 & 9 \\
9 & -120 & 10 & 4 \\
\hline
\end{tabular}

cryopreservation was determined after harvesting cells with $1 X$ TrypLE $^{\mathrm{TM}}$ Select and staining them with $0.4 \%$ Typan Blue stain (Invitrogen) for $1 \mathrm{~min}$. The cell count for stained (dead cells) and unstained (live cells) was performed with hemocytometer. The percent viability was calculated as Number of live cells $\times 100$

Number of dead cells

\section{Cryopreservation}

The expanded MSCs are usually cryopreserved before administration to patients. We wondered whether the culture of MSCs in different media affects the pre and post cryopreservation viability of MSCs. MSCs from P4 culture upon reaching $70-80 \%$ confluence underwent treatment with $1 \mathrm{X} \operatorname{TrypLE}^{\mathrm{TM}}$ Select, the harvested cells were centrifuged at $200 \mathrm{~g}$ for 2 min and then counted using hemocytometer. The viability of cells was calculated using Trypan Blue stain before cryopreservation. For cryopreservation, the desired final cell concentration of $1 \times 10^{6}$ cells $/ \mathrm{mL}$ was achieved using 1.350 $\mathrm{ml}$ pre-warmed media under experimentation as mentioned in (Table 1). The vials were transferred to $4^{\circ} \mathrm{C}$ for $10 \mathrm{~min}$ and then kept in Controlled Rate Freezer (CRF) (Planer ${ }^{\mathrm{TM}}$, UK) set with temperature conditions adapted from Can and Balci [23] followed by storing the cells at $-196^{\circ} \mathrm{C}$ in liquid nitrogen tank $\left(M^{2} E^{T M}\right.$, USA) (Table 2). The cells were removed after 4 weeks and post cryopreservation viability was calculated using Trypan Blue after following the thaw conditions for MSCs published previously [23]. The conditions include thawing the frozen cell vial in water bath for about $30 \mathrm{sec} / \mathrm{until}$ ice disappears from the wall of the vial. Then vial was centrifuged at 1000 rpm for $1 \mathrm{~min}$ and after removing the supernatant, the MSCs were re-suspended in freshly prepared culture media before assessing post cryopreservation viability with Trypan Blue.

\section{Statistical Analysis}

Statistical tests were performed using Prism GraphPad 5 and statistical differences were calculated using analysis of variance (ANOVA) with Bonferroni post-test or paired t-test wherever applicable.

\section{Results \\ Comparison of plastic surfaces from different brands for optimal growth of MSCs}

The adherence capability of MSCs depends on the plastic surface of the flasks. We first compared four different brands of culture flasks to evaluate the role of plastic surfaces on the adhesion and growth potential of MSCs. The MNCs from $B M$ and UCB were plated at concentration of $1 \times 10^{4} \mathrm{cells} / \mathrm{cm}^{2}$ in duplicates on Costar $^{\circledast}$, CellBIND ${ }^{\circledR}$, Greiner ${ }^{\circledR}$ and Tarsons ${ }^{\mathrm{TM}}$ culture flasks from each samples ( $\mathrm{n}=3$ for each tissue) and cultured in FBS, HS and pHPL added media and MesenGro ${ }^{\oplus}$. The quantification of the $\mathrm{P} 2$ cells derived from $\mathrm{P} 1$ cells obtained from BMMSCs, UCBMSCs and UCTMSCs was performed on these four types of culture flasks. The growth of MSCs derived from all the tissues in presence of MesenGro ${ }^{\circledR}$, and $\mathrm{FBS}, \mathrm{HS}$ and PHPL supplemented media on CellBIND ${ }^{\circledR}$ culture flasks outperformed Costar ${ }^{\oplus}$, Greiner $^{\ominus}$ and Tarsons ${ }^{\mathrm{TM}}$ flasks (Figure 1A). The differential adherence and growth potential of MSCs from BM and UCB MNCs cultured with PHPL supplemented media on the four different plastic flasks showed that almost $50 \%$ BM and 70\% UCB MNCs cultured in Tarsons $s^{\mathrm{TM}}$ flasks failed to adhere to the plastic surface even after 15 days while almost all the MNCs from BM and UCB cultured on Costar ${ }^{\oplus}$, CellBIND ${ }^{\circledR}$, Greiner $^{\circledR}$ culture flasks demonstrated uniform monolayer of MSCs within 15 days period (Figure1B). All the data presented henceforth were recorded from experiments performed using CellBIND ${ }^{\circledR}$ flasks. The culture conditions mentioned in (Table 1) were used to compare the isolation and expansion characteristics, morphology, immunophenotype and viability of the cells before and after cryopreservation ( $n=3$ in duplicates for each culture condition).

\section{Isolation of BM, UCT and UCB derived MSCs}

The initial plating of MNCs from BM and UCB in media with different serum supplements (FBS, HS, pHPL) and in STEMPRO ${ }^{\circ}$ MSC SFM and MesenGro ${ }^{\oplus}$ media showed differential isolation efficiency where $\mathrm{pHPL}$ supplemented media demonstrated the favorable environment for fibroblastoid MSCs isolated from BM andUCB. Similarly, the isolation and growth of fibroblastoid cells derived from UCT cultured in media with FBS, HS, pHPL and STEMPRO ${ }^{\circledR}$ MSC SFM and MesenGro ${ }^{\circledR}$ media were also variable where UCT MSCs required 12-15 days to attend $90 \%$ confluency of monolayer of fibroid cells of the implanted tissues on the $25 \mathrm{~cm}^{2}$ culture flask in presence of pHPL added media while almost 20-25 days on FBS and HS supplemented media (Figure 2A). In general, STEMPRO ${ }^{\circledR}$ MSC SFM media supported the least growth of MSCs from all the tissues under investigation whereas PHPL supplemented media provided the highest rate of isolation and proliferation to MSCs (Figures $\mathbf{2 B}$ and $\mathbf{2 C}$ ). 
A

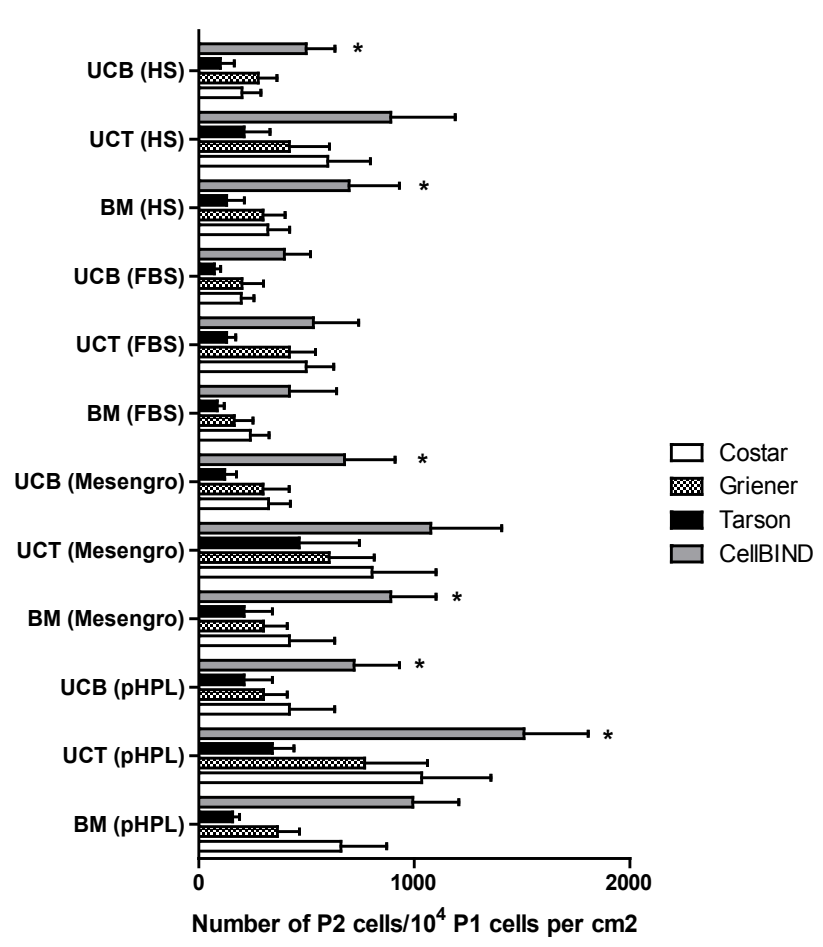

B
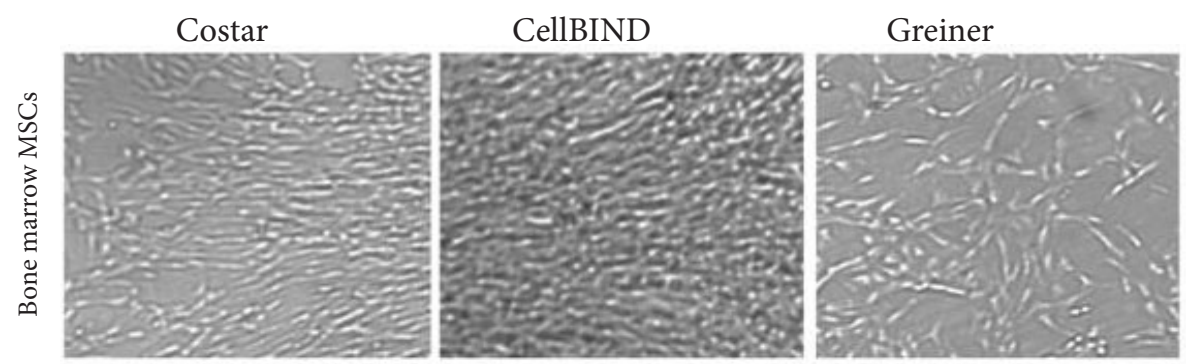

Tarsons
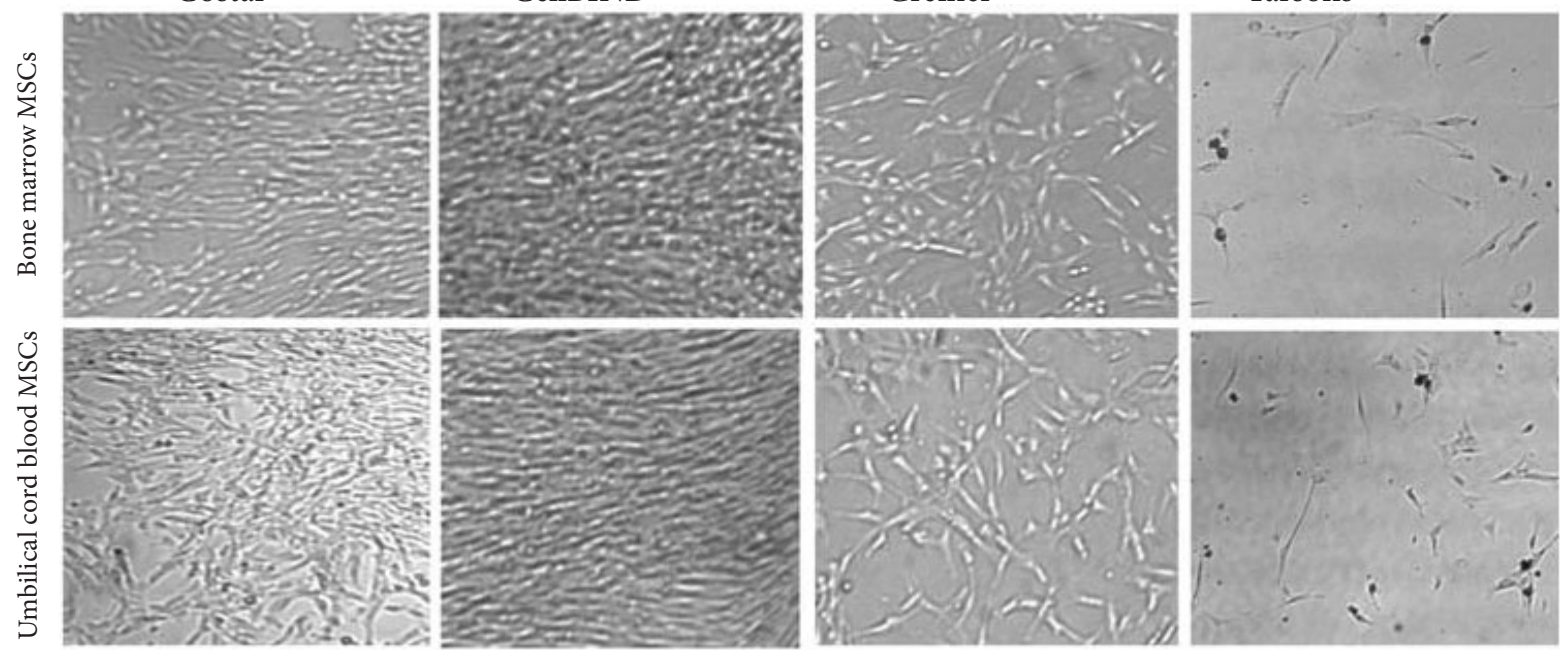

Figure 1. Effect of plastic surface on the growth of MSCs derived from BM, UCB and UCT. (A). The number of P2 cultured in FBS, HS, pHPL supplemented media and MesenGro ${ }^{\circledR}$ in four different plastic flasks, Costar ${ }^{\oplus}$, Griener ${ }^{\star}$, Tarsons ${ }^{\mathrm{Tm}}$ and CellBIND ${ }^{\circ}$ were harvested after seeding at $1 \times 10^{4} \mathrm{cells} / \mathrm{cm}^{2}$. The cells cultured using CellBIND ${ }^{\circ}$ flasks supported the highest number of MSCs from all tissues cultured under different media. (B). Photomicrographs of representative cultures at primary culture of BM and UCB MNCs at day 15 for pHPL supplemented media cultured in plastic brands from Costar ${ }^{\oplus}$, CellBIND ${ }^{\circ}$, Greiner ${ }^{\oplus}$ and Tarsons ${ }^{\text {tm }}$ demonstrated the differential effect of plastic brands on the growth of MSCs. Error bars represent standard error of mean and ${ }^{*}=\mathrm{P}<0.05$ represents the significant difference between MSCs cultured on CellBIND and other culture flasks in different types of media as evaluated with one-way ANOVA.

\section{Growth characteristics of BM, UCT and UCB derived MSCs}

The growth characteristics of BM, UCB and UCT derived MSCs were evaluated by assessing the cumulative population doubling and generation time in presence of different media described in (Table 1).

The MNCs were plated at concentration of $1 \times 10^{4}$ cells $/ \mathrm{cm}^{2}$ in duplicates on CellBIND ${ }^{\otimes}$ from each samples $(n=3)$ for 


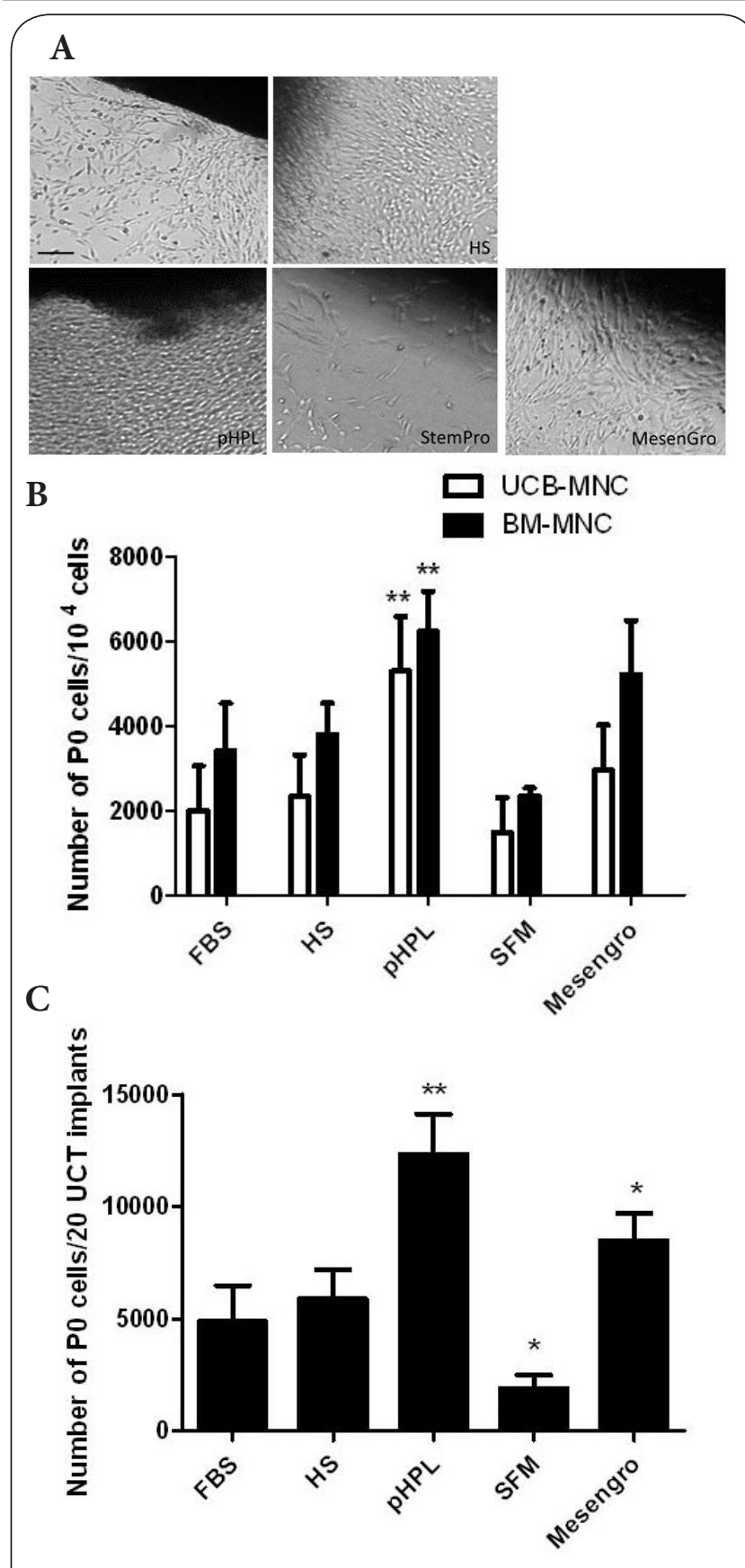

Figure 2. Effect of different culture conditions on the isolation of MSCs from BM MNCs, UCB MNCs and UCT implants. (A) The representative photomicrographs showing the morphology and differential growth potential of UCT derived MSCs cultured in FBS, HS and pHPL supplemented media and commercial media, $\mathrm{STEMPRO}^{\circ} \mathrm{MSC}^{\mathrm{S} F M}$ and MesenGro ${ }^{\circ}$ by day 15 . Scale bar $=200$ $\mu \mathrm{m}$. (B) The number of MSCs derived from BM and UCB MNCs when seeded at the density of $1 \times 10^{4}$ cells $/ \mathrm{cm}^{2}$ of CellBIND ${ }^{\circ}$ flasks ( $\mathrm{n}=6$ for each) in different culture media. (C) The number of MSCs derived from 20 implants of UCT in presence of different culture media conditions. Overall, pHPL supplemented media yielded highest number of MSCs as compared to FBS, HS supplemented and commercial media from BM, UCB and UCT. Error bars represent standard error of mean where $* \mid * *=\mathrm{P}<0.05 / 0.01$ and represents significant difference between FBS supplemented media and other media under investigations. culture conditions to evaluate the morphology and growth characteristic of the MSCs derived from BM, UCB and UCT. The MNCs from BM and UCB were devoid of hematopoietic cell contamination due to double density gradient centrifugation with Ficoll Paque Premium $(1.077 \mathrm{~g} / \mathrm{ml}$ and $1.073 \mathrm{~g} / \mathrm{ml})$.

The HS supplemented media showed relatively enhanced expansion rate of MSCs though it was not significantly different than that of FBS. However, pHPL supplemented media led to significantly higher expansion rate of MSCs than that of media supplemented with FBS/HS and STEMPRO ${ }^{\circledR}$ MSC SFM. The expansion rate of MSCs on MesenGro ${ }^{\circledR}$ was almost equivalent to that of $\mathrm{pHPL}$, although growth in $\mathrm{pHPL}$ was superior in all the culture conditions (Figures $3 \mathrm{~A}, 3 \mathrm{~B}$ and $3 \mathrm{C}$ ). In addition to expansion rate, the generation time assessed for P2 and P5 were minimal in PHPL supplemented media for all the types of MSCs under investigation (Figures 3D, 3E and 3F). The morphology of growing MSCs under serum containing media varied from those growing in serum free media. The FBS, HS and pHPL supplemented media supported the growth of MSCs with elongated spindle shaped morphology from primary culture and the passages thereafter.

\section{Immune phenotype}

The MSCs derived from all samples were analyzed at P4 for typical MSCs positive markers, CD 70, CD 90, CD 105 and negative markers CD 45, CD 34 and HLA-DR derived from BM, UCB and UCT. We evaluated the expression of these markers on P4 the MSCs derived BM, UCB and UCT cultures in various culture media and confirmed that despite the difference in the culture media, the expression of positive markers were more than $95 \%$ while that of negative markers were less than 5\% (Table 3). Furthermore, there was no statistically significant difference for any marker among MSCs derived from BM, UCB and UCT which were cultured in FBS, HS, pHPL supplemented media, STEMPRO ${ }^{\circledR}$ MSC SFM $^{\circledR}$ and MesenGro ${ }^{\circledR}$ media.

\section{Pre and Post cryopreservation viability}

Before MSCs administration, viability of stored MSCs is assessed as cells tend to lose their viability during cryopreservation. In most clinical settings, cryopreserved MSCs are used for infusion. Therefore, we evaluated the viability of the samples cultured using five different culture conditions as mentioned in (Table 1) which were cryopreserved for one month. The MSCs were stained with Trypan blue and viability was calculated using hemocytometer. Even though, the expansion potentials vary for different culture condition, there was no significant difference in the viability of the MSCs before and after one month long cryopreservation among these samples indicating that culture and storage of cells in different media lack effects on viability. (Figures 4A and 4B).

\section{Discussion}

Mesenchymal stem cells have emerged as the key cellular 


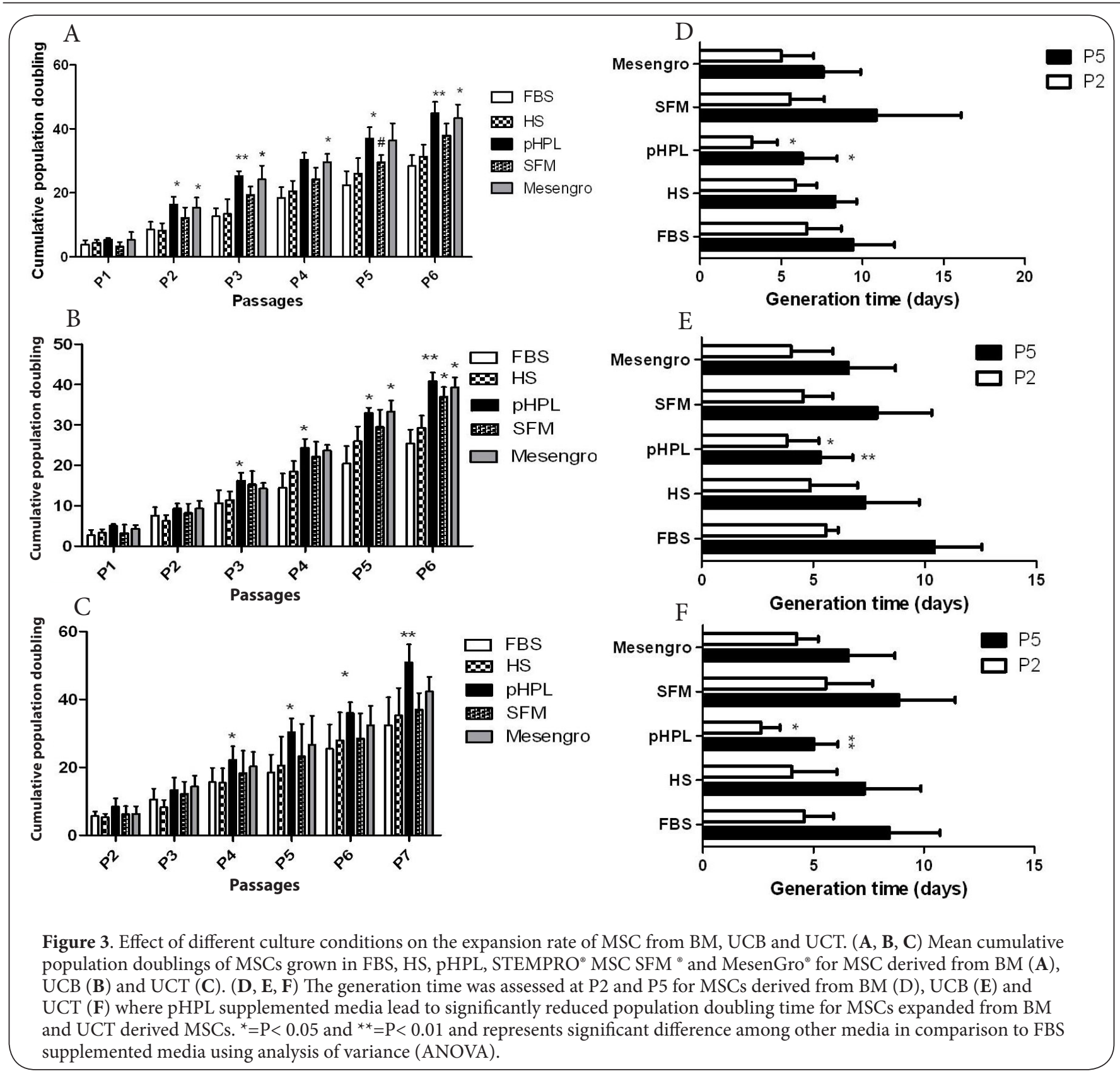

agents for the regenerative, immune and reparative therapies. MSCs inherit unique properties, ease of accessibility from various tissue sources, multipotency and rapid ex vivo expansion capability. The limitation in the number of stem cells in BM aspirates (the most common source for MSCs) and the concurrent need of large number of MSCs for therapeutic applications require ex vivo culture. In order to achieve the production of safe and clinical grade MSCs in sufficient quantity to meet the therapeutic dosage, the optimization of culture conditions in the laboratory are necessary. The ex vivo culture involves appropriate selection of culture conditions such as culture media, serum supplementation, plastic surface and cell density for optimized production of clinical grade MSCs $[9,10]$. Initially, FBS supplemented media were added for fulfillment of growth factors. However, use of FBS consists of risk for transmission of zoonotic diseases along with immunological allergic reactions [24-27]. Hence, humanized system based on incorporation of human serum or blood products as growth supplement for propagation of MSCs were introduced [14-17].

Many groups have published their success in isolation and expansion of MSCs from UCB, UCT, BM and other tissues using human serum, $\mathrm{pHPL}$, platelet rich plasma and cord blood $[14,16,17,29]$. In addition, there have been several studies 

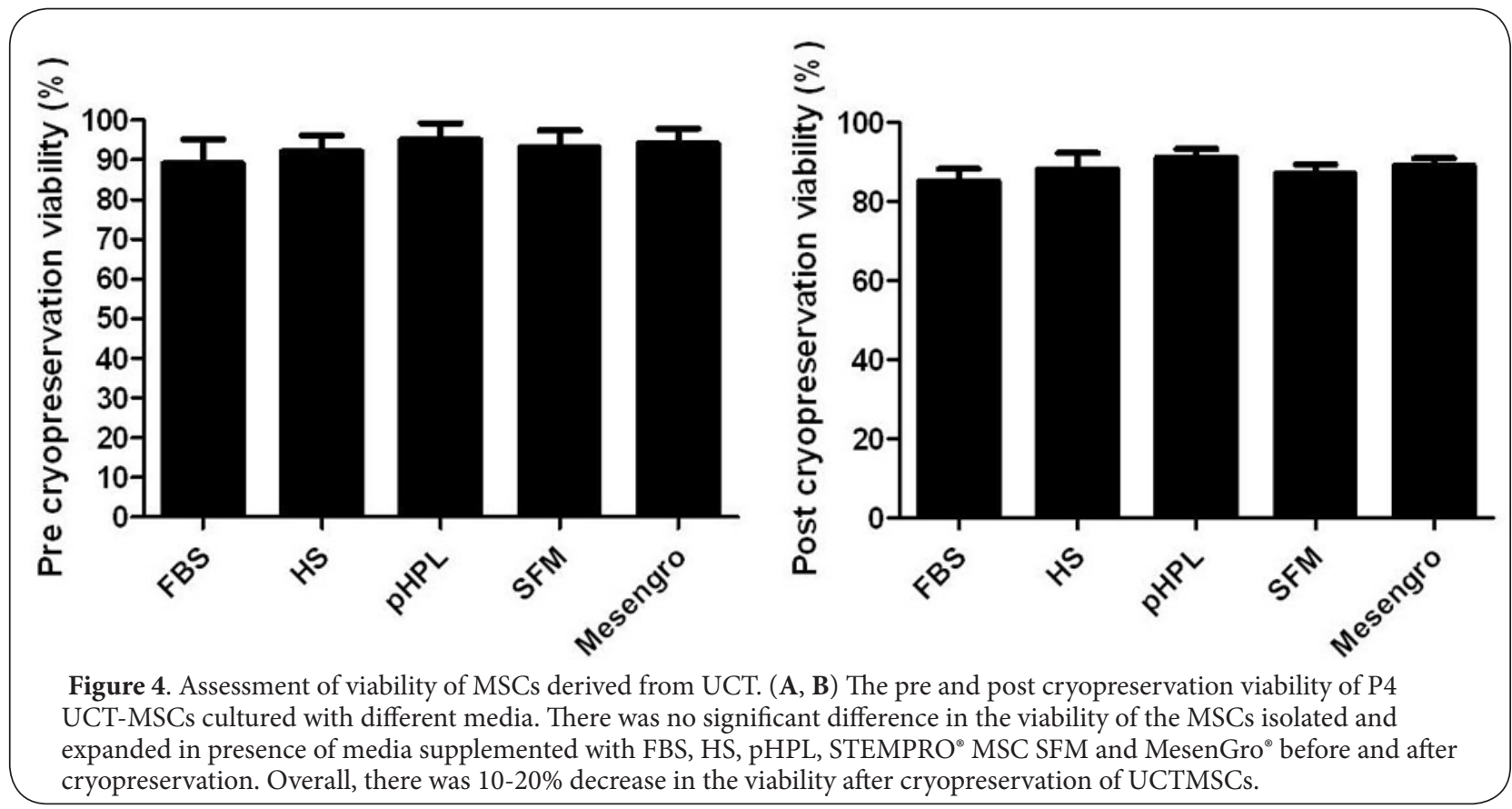

Table 3. The expression profile of positive and negative markers for MSCs derived from BM, UCB and UCT cultures in presence of different culture media.

\begin{tabular}{|c|c|c|c|c|c|c|}
\hline Markers (\%) & FBS & HS & pHPL & SFM & Mesengro & \\
\hline CD 34 & 1.32 & 1.92 & 0.98 & 1.45 & 1.84 & \\
\hline $\mathrm{CD} 45$ & 2.87 & 1.89 & 1.97 & 3.47 & 1.94 & \\
\hline HLA-DR & 1.06 & 0.76 & 0.96 & 1.18 & 1.65 & $\mathbf{B M}$ \\
\hline CD 73 & 96.45 & 97.15 & 98.45 & 96.98 & 96.32 & \\
\hline CD 90 & 97.32 & 98.74 & 97.32 & 98.63 & 97.33 & \\
\hline CD 105 & 96.76 & 95.91 & 98.79 & 95.76 & 97.72 & \\
\hline CD 34 & 2.02 & 3.32 & 1.98 & 2.25 & 3.84 & \\
\hline $\mathrm{CD} 45$ & 4.72 & 2.59 & 2.88 & 3.78 & 2.98 & \\
\hline HLA-DR & 1.56 & 2.35 & 1.90 & 2.18 & 1.63 & UCB \\
\hline CD 73 & 95.85 & 95.35 & 98.15 & 94.91 & 95.78 & \\
\hline CD 90 & 97.92 & 97.86 & 98.92 & 96.86 & 95.26 & \\
\hline CD 105 & 94.55 & 93.91 & 97.19 & 95.34 & 96.42 & \\
\hline CD 34 & 1.12 & 1.67 & 0.96 & 1.65 & 1.44 & \\
\hline CD 45 & 1.45 & 1.89 & 1.17 & 2.27 & 1.14 & \\
\hline HLA-DR & 1.33 & 1.32 & 0.98 & 1.88 & 1.65 & UCT \\
\hline CD 73 & 97.15 & 98.17 & 97.40 & 96.68 & 95.69 & \\
\hline CD 90 & 98.72 & 97.94 & 99.12 & 97.50 & 98.42 & \\
\hline CD 105 & 97.66 & 96.11 & 97.96 & 95.72 & 97.91 & \\
\hline
\end{tabular}

on comparing different protocols for production of MSCs from various human tissues. Studies have compared various culture media, animal origin versus human origin growth supplements, brand of culture flasks, and seeding densities for cells using $B M, U C B, U C T, A T$ and chorionic villi $[11,12,29-34]$.
The age and health condition of donor is crucial for optimized production of MSCs from BM [35]. In our study, the collection of $\mathrm{BM}$ was from healthy donors with age range of 30-40 years while UCB and UCT were obtained from healthy mothers with age range of 20-30 years screened as negative for Hepatitis A, B, HIV 1, 2 and Syphilis and had full term caesarean section delivery. Due to narrow age difference in our BM donor population, we fail to detect any significant age related variation in the expansion potential of BM MSCs among these samples. Moreover, we incorporated dual density gradient centrifugation where BM MNCs obtained with $1.077 \mathrm{~g} / \mathrm{ml}$ Ficoll Paque-Premium were processed with $1.073 \mathrm{~g} / \mathrm{ml}$ Ficoll Paque Premium so as to obtain MNCs consist of pure population of low density MNCs comprised of MSCs which were subsequently cultured under different culture conditions. It is to be noted that Ficoll Paque Premium is compliant with GMP manufacturing conditions, possesses lower endotoxin levels (www.gelifesciences.com) and is reported to yield relatively higher number of MSCs from various human and non-human sources including $C B$ and UCB compared with other density gradient agents $[36,37]$. Few studies have also compared isolation protocols using Ficoll gradient centrifugation with other MSCs enrichment strategies like RossetteSep ${ }^{\circledast}$ (StemCell Technologies ${ }^{\mathrm{TM}}$, Canada) or magnetic-bead based CD 271 sorting (Miltenyi ${ }^{\mathrm{TM}}$ Biotech $\mathrm{GmbH}$, Germany) $[12,38]$ concluded that such strategies help in obtaining BM MSCs devoid of small, loosely adherent and contaminant round cells but fail to offer any advantage in terms of proliferation kinetics.

In this report, we have evaluated the effect of some of the other key parameters on the expansion potential of 
BM, UCB and UCT. The type of the surface coating on the plastic surfaces used for the isolation and propagation of MSCs was evaluated using four different brands of flasks, Costar $^{\circledast}$, CellBIND ${ }^{\circledR}$, Greiner $^{\circledast}$ and Tarsons ${ }^{\mathrm{T}}{ }^{\mathrm{M}}$. According to the manufactures, all the above flasks were tissue culture treated; CellBIND ${ }^{\circledR}$ flasks in addition had unique surface treatment. In general, the tissue culture treatment makes the polysterene surface hydrophilic and negatively charged when medium is added. CellBIND ${ }^{\circledR}$ surface undergoes plasma surface treatment which produces the core polymer chain and increases oxygen containing functional groups thereby resulting in improved hydrophilicity and wettability under both serum and serum-free conditions. Such coating is known to improve cell spreading and attachment [39-41]. In all the experiments, CellBIND ${ }^{\circledR}$ surface provided the most favorable environment for MSCs derived from the primary culture of $\mathrm{BM}, \mathrm{UCB}$ and UCT with the media supplemented with $\mathrm{PHPL}$.

The isolation efficiency of MSCs derived from BM, UCB and UCT varied on the media under investigation. Among these different media, the isolation of MSCs from BM MNC, UCB MNC and UCT was best supported with media supplemented with pHPL. The MesenGro ${ }^{\circledR}$ media led to relatively better cell attachment than the media supplemented with FBS and HS. In our study, isolation of MSCs from BM MNC, UCB MNC and UCT was least supported on STEMPRO ${ }^{\circledR}$ MSC SFM media as compared to other media. Jung et al., [20] and Hartmann et al., [42] also failed to obtain efficient attachment and growth of primary BM-hMSCs and umbilical cord, respectively. Recent studies have used STEMPRO ${ }^{\circledR}$ MSC SFM media to investigate primary cell isolation, expansion potential, mesoderm differentiation, and gene expression analysis of MSCs derived from human BM and adipose tissues and found comparable propagation and differentiation potential with MSCs cultured with FBS containing media $[43,44]$. In another study, Patrikoski et al., [45] reported that initial adhesion of isolated MSCs from adipose tissues with STEMPRO ${ }^{\circledR}$ MSC SFM media was only possible on the carboxyl coated plastic indicating the role of culture conditions on successful isolation and propagation of MSCs cultured with STEMPRO ${ }^{\circledR}$ MSC SFM media.

We then determined the expansion potential of in-house produced serum and serum-free commercial culture conditions. We used alpha MEM as our base medium because it has been shown to support primary and subsequent isolation [29]. In addition, we opted the optimum seeding density of $1 \times 10^{4} \mathrm{cell} / \mathrm{s} / \mathrm{cm}^{2}$ for BM and UCB MNCs and during subculture of MSCs till P7. Several studies have advocated the importance of the seeding density on optimum expansion potential. The lower MSCs seeding density leads to higher growth potential due to maximum availability of nutrients per cell, longer exponential growth phase and lack of contact inhibition $[\mathbf{2 9}, \mathbf{4 6}, \mathbf{4 7}]$. Interestingly, UCT derived MSCs demonstrated the highest population doubling at the seeding density of $1 \times 10^{4} \mathrm{cell} / \mathrm{s} / \mathrm{cm}^{2}$ for all the culture media under investigation indicating that different tissues required optimization of seeding density to gain the highest yield of MSCs. Furthermore, MSCs cultured in media containing pHPL outperformed the MSCs cultured in FBS with respect to growth potential especially for later passages whereas MSCs expanded in MesenGro ${ }^{\circledR}$ and STEMPRO ${ }^{\circledR}$ MSC SFM showed relatively lower population doubling than those cultured in PHPL. One reason could be the lower seeding density because higher seeding density $\left(1 \times 10^{6} \mathrm{cells} / \mathrm{cm}^{2}\right)$ has been shown to support optimized growth potential of MSCs with the usage of these commercial media (www.stemrd.com; www.invitrogen.com) [19]. The generation time was also significantly improved with the PHPL supplemented media as compared to other culture media under investigation.

Despite the differences in the growth conditions, the MSCs obtained from BM, UCB and UCT displayed similar characteristics when assessed for immune-phenotypic properties. We assessed for the presence of positive markers, CD 70, CD 90, CD 105 and negative markers CD 45, CD 34 and HLA-DR for MSCs derived from BM, UCB and UCT; the positive markers counted for more than $95 \%$ MSCs and negative markers for less than $5 \%$. This suggests that supplementation of growth factors through animal origin human origin or via recombinant growth factors is devoid of any alteration in immune phenotypes of the cultured MSCs. Furthermore, the evaluation of pre and post cryopreserved samples cultured in different culture conditions yielded no significant difference in viability. It has been indicated that cryopreservation using controlled rate freezing with $5 \%$ dimethyl sulfoxide (DMSO) is important for obtaining higher post-cryopreservation viability which is crucial for clinical applicability of cryopreserved MSCs $[\mathbf{2 4 , 4 8}]$.

We were able to isolate MSCs from all the tissues using the culture conditions under investigation; however, expansion potential was highest for MSCs cultured in pHPL. Therefore, our study supports the use of pHPL as an effective alternative growth supplement for the optimal expansion of MSCs from $\mathrm{BM}, \mathrm{UCB}$ and UCT. The different methods for the production of pHPL are available and easily obtained from whole blood, buffy coat derived pooled platelet concentrate $[22,49]$. Moreover, pHPL can also be derived from platelet concentrates after the expiry period (4-5 days) [12]. Our work (data not provided) also supports that expired platelets can be used to produce effective pHPL. Furthermore, various studies have confirmed the implementation of $\mathrm{PHPL}$ as a human origin supplement for GMP-compliant large scale production of clinical grade MSCs from various human tissues including BM and UCT $[42,49]$. Pooled human platelet lysate (pHPL) is a great source of growth factors and an economical, convenient and efficient avenue for isolation and expansion of clinical grade MSCs from various human tissues. The MSCs grown in pHPL supplemented media demonstrated similar growth and immunological profile when compared to those growing in media supplemented with FBS [12,17,22,34]. Moreover, its supplementation to MSCs failed to induce expression of 
Inamdar et al. Journal of Regenerative Medicine \& Tissue Engineering 2013, http://www.hoajonline.com/journals/pdf/2050-1218-2-10.pdf

functional class II major histocompatibility complex antigen, indicator of immune stimulation [51]. In addition, BM MSCs expanded in culture medium supplemented with human serum have shown significantly higher property of decreasing CD3/CD28-mediated T-cell activation and a comparable morphology and phenotype to the MSCs grown in the fetal calf serum [31].

In our study, UCT derived MSCs demonstrated lowest generation time when compared to other media under investigation for BM UCB and UCT derived tissues. UCT is a rich source of MSCs and many laboratories have been able to isolate large number of multipotent MSCs with $100 \%$ isolation ability and capability to originate different cell lineages. Furthermore, the transcription profile and immunological characteristics are very well studied [51-54]. Therefore, UCT can be an atractive alternative source for the off-the-shelf product of human MSCs for autologous or allogenic treatment for various pathological conditions.

\section{Conclusion}

Our report provides comprehensive evaluation of the serum containing and serum free media on the morpholical and growth charateristics of MSCs derived from BM, UCB and UCT and concludes that PHPL supplemented media provide cost effective and efficacious way to produce clinical grade MSCs from various human tissues as opposed to commercial media. We showed that UCT can be an alternative option for large number of MSCs and unique surface treatment of cell culture flasks such as CellBIND ${ }^{\otimes}$ facilitate large scale production of MSCs from various human tissues.

\section{Competing interests}

The authors declare that they have no competing interests.

\section{Authors' contributions}

\begin{tabular}{|l|c|c|}
\hline Authors' contributions & AAI & ACI \\
\hline Research concept and design & $\checkmark$ & $\checkmark$ \\
\hline Collection and/or assembly of data & $\checkmark$ & $\checkmark$ \\
\hline Data analysis and interpretation & $\checkmark$ & -- \\
\hline Writing the article & $\checkmark$ & $\checkmark$ \\
\hline Critical revision of the article & $\checkmark$ & -- \\
\hline Final approval of article & $\checkmark$ & $\checkmark$ \\
\hline Statistical analysis & $\checkmark$ & -- \\
\hline
\end{tabular}

Acknowledgement

We are thankful to the hospitals and human volunteers who provided the tissue samplings for conducting this research study.

Publication history

Received: 10-Apr-2013 Revised: 27-Aug-2013

Accepted: 3-Oct-2013 Published: 29-Oct-2013

\section{References}

1. Giordano A, Galderisi $U$ and Marino IR. From the laboratory bench to the patient's bedside: an update on clinical trials with mesenchymal stem cells. J Cell Physiol. 2007; 211:27-35. | Article | PubMed

2. Trounson A, Thakar RG, Lomax $G$ and Gibbons $D$. Clinical trials for stem cell therapies. BMC Med. 2011; 9:52. | Article | PubMed Abstract | PubMed Full Text

3. Meirelles Lda S, Fontes AM, Covas DT and Caplan AI. Mechanisms involved in the therapeutic properties of mesenchymal stem cells. Cytokine Growth Factor Rev. 2009; 20:419-27. | Article | PubMed

4. Atoui R and Chiu RC. Mesenchymal stromal cells as universal donor cells. Expert Opin Biol Ther. 2012; 12:1293-7. I Article I PubMed

5. Nauta AJ and Fibbe WE. Immunomodulatory properties of mesenchymal stromal cells. Blood. 2007; 110:3499-506. | Article | PubMed

6. Conget PA and Minguell JJ. Phenotypical and functional properties of human bone marrow mesenchymal progenitor cells. J Cell Physiol. 1999; 181:67-73. | Article | PubMed

7. Caplan Al and Bruder SP. Mesenchymal stem cells: building blocks for molecular medicine in the 21st century. Trends Mol Med. 2001; 7:25964. | Article | PubMed

8. Dominici M, Le Blanc K, Mueller I, Slaper-Cortenbach I, Marini F, Krause D, Deans R, Keating A, Prockop D and Horwitz E. Minimal criteria for defining multipotent mesenchymal stromal cells. The International Society for Cellular Therapy position statement. Cytotherapy. 2006; 8:315-7. | Article | PubMed

9. Mannello F and Tonti GA. Concise review: no breakthroughs for human mesenchymal and embryonic stem cell culture: conditioned medium, feeder layer, or feeder-free; medium with fetal calf serum, human serum, or enriched plasma; serum-free, serum replacement nonconditioned medium, or ad hoc formula? All that glitters is not gold! Stem Cells. 2007; 25:1603-9. | Article | PubMed

10. Ankrum J and Karp JM. Mesenchymal stem cell therapy: Two steps forward, one step back. Trends Mol Med. 2010; 16:203-9. I Article PubMed Abstract | PubMed Full Text

11. Kern S, Eichler H, Stoeve J, Kluter $\mathrm{H}$ and Bieback K. Comparative analysis of mesenchymal stem cells from bone marrow, umbilical cord blood, or adipose tissue. Stem Cells. 2006; 24:1294-301. I Article I PubMed

12. Bieback K, Kern S, Kocaomer A, Ferlik K and Bugert P. Comparing mesenchymal stromal cells from different human tissues: bone marrow, adipose tissue and umbilical cord blood. Biomed Mater Eng. 2008; 18:S71-6. | PubMed

13. Spees JL, Gregory CA, Singh H, Tucker HA, Peister A, Lynch PJ, Hsu SC, Smith J and Prockop DJ. Internalized antigens must be removed to prepare hypoimmunogenic mesenchymal stem cells for cell and gene therapy. Mol Ther. 2004; 9:747-56. | Article | PubMed

14. Stute N, Holtz K, Bubenheim M, Lange C, Blake F and Zander AR. Autologous serum for isolation and expansion of human mesenchymal stem cells for clinical use. Exp Hematol. 2004; 32:1212-25. | Article | PubMed

15. Doucet C, Ernou I, Zhang Y, Llense JR, Begot L, Holy X and Lataillade JJ. Platelet lysates promote mesenchymal stem cell expansion: a safety substitute for animal serum in cell-based therapy applications. J Cell Physiol. 2005; 205:228-36. | Article | PubMed

16. Kocaoemer A, Kern S, Kluter $\mathrm{H}$ and Bieback K. Human AB serum and thrombin-activated platelet-rich plasma are suitable alternatives to fetal calf serum for the expansion of mesenchymal stem cells from adipose tissue. Stem Cells. 2007; 25:1270-8. I Article I PubMed

17. Schallmoser K, Bartmann C, Rohde E, Reinisch A, Kashofer K, Stadelmeyer E, Drexler C, Lanzer G, Linkesch W and Strunk D. Human platelet lysate can replace fetal bovine serum for clinical-scale expansion of functional mesenchymal stromal cells. Transfusion. 2007; 47:1436-46. | Article | PubMed

18. Jung J, Moon N, Ahn JY, Oh EJ, Kim M, Cho CS, Shin JC and Oh IH. Mesenchymal stromal cells expanded in human allogenic cord blood serum display higher self-renewal and enhanced osteogenic potential. Stem Cells Dev. 2009; 18:559-71. I Article I PubMed

19. Chase LG, Lakshmipathy $U$, Solchaga LA, Rao MS and Vemuri MC. A novel serum-free medium for the expansion of human mesenchymal 
stem cells. Stem Cell Res Ther. 2010; 1:8. | Article | PubMed Abstract | PubMed Full Text

20. Jung $S$, Panchalingam KM, Rosenberg $L$ and Behie LA. Ex vivo expansion of human mesenchymal stem cells in defined serum-free media. Stem Cells Int. 2012; 123030. | Article | PubMed Abstract | PubMed Full Text

21. Yang S, Pilgaard L, Chase LG, Boucher S, Vemuri MC, Fink T and Zachar V. Defined xenogeneic-free and hypoxic environment provides superior conditions for long-term expansion of human adipose-derived stem cells. Tissue Eng Part C Methods. 2012; 18:593-602. | Article | PubMed

22. Kurita $M$, Aiba-Kojima E, Shigeura T, Matsumoto $D$, Suga $H$, Inoue $K$, Eto $\mathrm{H}$, Kato $\mathrm{H}$, Aoi $\mathrm{N}$ and Yoshimura K. Differential effects of three preparations of human serum on expansion of various types of human cells. Plast Reconstr Surg. 2008; 122:438-48. | Article | PubMed

23. Can $A$ and Balci D. Isolation, culture, and characterization of human umbilical cord stroma-derived mesenchymal stem cells. Methods $\mathrm{Mol}$ Biol. 2011; 698:51-62. | Article | PubMed

24. Tuschong L, Soenen SL, Blaese RM, Candotti F and Muul LM. Immune response to fetal calf serum by two adenosine deaminase-deficient patients after T cell gene therapy. Hum Gene Ther. 2002; 13:1605-10. I Article I PubMed

25. Selvaggi TA, Walker RE and Fleisher TA. Development of antibodies to fetal calf serum with arthus-like reactions in human immunodeficiency virus-infected patients given syngeneic lymphocyte infusions. Blood. 1997; 89:776-9. | PubMed

26. Mackensen A, Drager R, Schlesier M, Mertelsmann R and Lindemann A. Presence of IgE antibodies to bovine serum albumin in a patient developing anaphylaxis after vaccination with human peptide-pulsed dendritic cells. Cancer Immunol Immunother. 2000; 49:152-6. | Article | PubMed

27. Tonti GA and Mannello F. From bone marrow to therapeutic applications: different behaviour and genetic/epigenetic stability during mesenchymal stem cell expansion in autologous and foetal bovine sera? Int J Dev Biol. 2008; 52:1023-32. | Article | PubMed

28. Sotiropoulou PA, Perez SA, Salagianni M, Baxevanis CN and Papamichail $M$. Characterization of the optimal culture conditions for clinical scale production of human mesenchymal stem cells. Stem Cells. 2006; 24:462-71. | Article | PubMed

29. Bieback K, Hecker A, Kocaomer A, Lannert H, Schallmoser K, Strunk $\mathrm{D}$ and Kluter $\mathrm{H}$. Human alternatives to fetal bovine serum for the expansion of mesenchymal stromal cells from bone marrow. Stem Cells. 2009; 27:2331-41. | Article | PubMed

30. Pal R, Hanwate M, Jan M and Totey S. Phenotypic and functional comparison of optimum culture conditions for upscaling of bone marrow-derived mesenchymal stem cells. J Tissue Eng Regen Med. 2009; 3:163-74. | Article | PubMed

31. Grisendi G, Anneren C, Cafarelli L, Sternieri R, Veronesi E, Cervo GL, Luminari S, Maur M, Frassoldati A, Palazzi G, Otsuru S, Bambi F, Paolucci P, Pierfranco C, Horwitz E and Dominici M. GMP-manufactured density gradient media for optimized mesenchymal stromal/stem cell isolation and expansion. Cytotherapy. 2010; 12:466-77. | Article | PubMed

32. Ben Azouna N, Jenhani F, Regaya Z, Berraeis L, Ben Othman T, Ducrocq $E$ and Domenech J. Phenotypical and functional characteristics of mesenchymal stem cells from bone marrow: comparison of culture using different media supplemented with human platelet lysate or fetal bovine serum. Stem Cell Res Ther. 2012; 3:6. | Article | PubMed Abstract I PubMed Full Text

33. Stolzing A, Jones $E$, McGonagle $D$ and Scutt A. Age-related changes in human bone marrow-derived mesenchymal stem cells: consequences for cell therapies. Mech Ageing Dev. 2008; 129:163-73. | Article | PubMed

34. Koch TG, Thomsen PD and Betts DH. Improved isolation protocol for equine cord blood-derived mesenchymal stromal cells. Cytotherapy. 2009; 11:443-7. | Article | PubMed

35. Grisendi G, Anneren C, Cafarelli L, Sternieri R, Veronesi E, Cervo GL, Luminari S, Maur M, Frassoldati A, Palazzi G, Otsuru S, Bambi F, Paolucci P, Pierfranco C, Horwitz E and Dominici M. GMP-manufactured density gradient media for optimized mesenchymal stromal/stem cell isolation and expansion. Cytotherapy. 2010; 12:466-77. | Article | PubMed

36. Poloni A, Maurizi G, Serrani F, Mancini S, Discepoli G, Tranquilli AL, Bencivenga R and Leoni P. Human AB serum for generation of mesenchymal stem cells from human chorionic villi: comparison with other source and other media including platelet lysate. Cell Prolif. 2012; 45:66-75. | Article | PubMed

37. Curtis A, Forrester J, McInnes $C$ and Lawrie F. Adhesion of cells to polystyrene surfaces. J Cell Biol. 1983; 97: 1500-1506. | Article

38. van Kooten TG, Spijker HT and Busscher HJ. Plasma-treated polystyrene surfaces: model surfaces for studying cell-biomaterial interactions. Biomaterials. 2004; 25:1735-47. | Article | PubMed

39. Corning: Corning Cell Culture Surfaces: Corning ${ }^{\circledR}$ CellBIND ${ }^{\circledR}$ Surface. | Website

40. Hartmann I, Hollweck T, Haffner S, Krebs M, Meiser B, Reichart B and Eissner G. Umbilical cord tissue-derived mesenchymal stem cells grow best under GMP-compliant culture conditions and maintain their phenotypic and functional properties. J Immunol Methods. 2010; 363:80-9. | Article | PubMed

41. Lindroos B, Boucher S, Chase L, Kuokkanen H, Huhtala H, Haataja R, Vemuri $M$, Suuronen $R$ and Miettinen S. Serum-free, xeno-free culture media maintain the proliferation rate and multipotentiality of adipose stem cells in vitro. Cytotherapy. 2009; 11:958-72. | Article | PubMed

42. Chase LG, Yang S, Zachar V, Yang Z, Lakshmipathy U, Bradford J, Boucher $\mathrm{SE}$ and Vemuri MC. Development and characterization of a clinically compliant xeno-free culture medium in good manufacturing practice for human multipotent mesenchymal stem cells. Stem Cells Trans/ Med. 2012; 1:750-8. | Article | PubMed Abstract | PubMed Full Text

43. Patrikoski M, Juntunen M, Boucher S, Campbell A, Vemuri MC, Mannerstrom B and Miettinen S. Development of fully defined xenofree culture system for the preparation and propagation of cell therapycompliant human adipose stem cells. Stem Cell Res Ther. 2013; 4:27. I Article | PubMed Abstract | PubMed Full Text

44. Neuhuber B, Swanger SA, Howard L, Mackay A and Fischer I. Effects of plating density and culture time on bone marrow stromal cell characteristics. Exp Hematol. 2008; 36:1176-85. | Article | PubMed Abstract | PubMed Full Text

45. Fossett $E$ and Khan WS. Optimising human mesenchymal stem cell numbers for clinical application: a literature review. Stem Cells Int. 2012; 2012:465259. | Article | PubMed Abstract | PubMed Full Text

46. Haack-Sorensen $M$ and Kastrup J. Cryopreservation and revival of mesenchymal stromal cells. Methods Mol Biol. 2011; 698:161-74. | Article I PubMed

47. Schallmoser K and Strunk D. Preparation of pooled human platelet lysate (pHPL) as an efficient supplement for animal serum-free human stem cell cultures. J Vis Exp. 2009: doi:pii: 1523. | Article | PubMed

48. Bocelli-Tyndall C, Zajac P, Di Maggio N, Trella E, Benvenuto F, lezzi G, Scherberich A, Barbero A, Schaeren S, Pistoia V, Spagnoli G, Vukcevic M, Martin I and Tyndall A. Fibroblast growth factor $\mathbf{2}$ and platelet-derived growth factor, but not platelet lysate, induce proliferation-dependent, functional class II major histocompatibility complex antigen in human mesenchymal stem cells. Arthritis Rheum. 2010; 62:3815-25. | Article | PubMed

49. Romanov YA, Svintsitskaya VA and Smirnov VN. Searching for alternative sources of postnatal human mesenchymal stem cells: candidate MSClike cells from umbilical cord. Stem Cells. 2003; 21:105-10. | Article | PubMed

50. Lu LL, Liu YJ, Yang SG, Zhao QJ, Wang X, Gong W, Han ZB, Xu ZS, Lu YX, Liu D, Chen ZZ and Han ZC. Isolation and characterization of human umbilical cord mesenchymal stem cells with hematopoiesis-supportive function and other potentials. Haematologica. 2006; 91:1017-26. | Article | PubMed

51. Secco M, Zucconi E, Vieira NM, Fogaca LL, Cerqueira A, Carvalho MD, Jazedje T, Okamoto OK, Muotri AR and Zatz M. Multipotent stem cells from umbilical cord: cord is richer than blood! Stem Cells. 2008; 26:14650. | Article | PubMed 
52. Pereira WC, Khushnooma I, Madkaikar M and Ghosh K. Reproducible methodology for the isolation of mesenchymal stem cells from human umbilical cord and its potential for cardiomyocyte generation. J Tissue Eng Regen Med. 2008; 2:394-9. I Article I PubMed

53. Troyer DL and Weiss ML. Wharton's jelly-derived cells are a primitive stromal cell population. Stem Cells. 2008; 26:591-9. | Article | PubMed Abstract I PubMed Full Text

54. Reinisch A and Strunk D. Isolation and animal serum free expansion of human umbilical cord derived mesenchymal stromal cells (MSCs) and endothelial colony forming progenitor cells (ECFCs). J Vis Exp. 2009: I Article I PubMed

\section{Citation:}

Inamdar AA and Inamdar AC. Culture conditions for growth of clinical grade human tissue derived mesenchymal stem cells: comparative study between commercial serum-free media and human product supplemented media. J Regen Med Tissue Eng. 2013; 2:10. http://dx.doi.org/10.7243/2050-1218-2-10 